SILVERY BLUE Glaucopsyche lygdamus couperi Grote A common early season species of woodland areas. Adults are found from mid-May to late June.

SPRING AZURE Celastrina argiolus argentata Fletcher I am not certain about the subspecific designation with this species; argentata was described from Cartwright, Manitoba but most eastern Manitoba populations show a degree of intergradation between argentata and pseudargiolus. This is one of the first butterflies on the wing in the spring; there is a first brood in May and a second brood in early July.

\section{LITERATURE CITED}

Brodie, H. J., 1969. Lepidoptera of Victoria Beach, Manitoba (as taken by myself up to August 1925). Bull. Assoc. Minnesota Ent., $2: 70-73$.

Brooks, G. S. 1942. A check list of the butterflies of Manitoba. Canadian Ent., 74 : 31-36.

Masters, J. H. \& J. T. Sorensen, 1967. Bionomic notes on the satyrid butterfly Oeneis macounii at Riding Mountain, Manitoba. Blue Jay, $25: 38-40$.

\title{
A LIST OF BUTTERFLIES TAKEN AT SANDILANDS PROVINCIAL FOREST, MANITOBA
}

\author{
by John H. Masters, P.O. Box 7511, St. Paul, Minnesota
}

Sandilands Provincial Forest comprises the southern Manitoba segment of La Petite Montagne de Cypres (or Sandilands Ridge) which extends from Victoria Beach on Lake Winnipeg through the Belair, Agassiz and Sandilands Forest Reserves into Roseau County, Minnesota. This entire ridge was formed as a beach from wave action on glacial Lake Agassiz 12,000 years ago. The area is characterized by shallow sandy soil (hence the name sandilands) and mixed deciduousconiferous forests. Unlike the areas of Manitoba to the west of this ridge, this land has not been cultivated in the past and is now in the public domain as Provincial Forest. The forests have not been cut over for many years and the forest reserve is cut by numerous fire control roads. It is an excellent area for natural history studies.

For the past six years I have been studying butterfly distribution in Manitoba and have recently started to write a series of articles dealing with Manitoba Provincial Parks. The second of these (Masters, 1972) deals with the butterflies of Grand Beach Provincial Park and Belair Forest Reserve which is the northern segment of La Petite Montagne de Cypres. Because I have spent considerably more time working in Sandilands than in the
Belair Forests, I have a much more complete list of the butterflies occurring here. It would seem worthwhile, therefore, to list the species recorded from Sandilands. This list follows. Species that are marked with an asterisk have not been taken by me but have been taken by others or recorded elsewhere as occurring at Sandilands.

\section{PAPILIONIDAE :}

Papilio polyxenes asterius Stoll*, Papilio glaucus canadensis Rothschild \& Jordan.

\section{PIERIDAE :}

Pieris protodice protodice Boisduval \& LeConte, Pieris napi oleracea Harris, Pieris rapae rapae (Linnaeus), Colias eurytheme vurytheme Boisduval, Colias philodice philodice Godart, Colias interior interior Scudder, Eurema lisa (Boisduval \& LeConte), Nathalis iole (Boisduval), Euchloe ausonidies Lucas ssp.

DANAIDAE :

Danaus plexippus plexippus (Linnaeus).

\section{SATYRIDAE :}

Lethe anthedon borealis (Clark), Lethe eurydice eurydice (Johansson), Euptychia cymela cymela (Cramer), Coenonympha tullia inornata Edwards, Cercyonis pegala nephele (Kirby), Erebia 
disa mancinus Doubleday*, Erebia discoidalis discoidalis (Kirby), Oeneis uhleri varuna Edwards*, Oeneis macounii (Edwards), Oeneis jutta ascerta Masters \& Sorensen*.

\section{NYMPHALIDAE:}

Limenitis arthemis arthemis (Drury), Limenitis archippus archippus (Cramer), Vanessa atalanta rubria (Fruhstorfer), Cynthia virginiensis (Drury), Cynthia cardui (Linnaeus), Precis coenia coenia (Hubner)*, Nymphalis $j$-album j-album (Boisduval \& LeConte), Nymphalis antiopa antiopa (Linnaeus), Nymphalis milberti milberti (Godart), Polygonia interrogationis (Fabricius)*, Polygonia satyrus neomarsyas dos Passos, Polygonia progne (Cramer), Phyciodes tharos tharos (Drury), Phyciodes batesii (Reakirt), Chlosyne nycteis Doubleday ssp., Chlosyne harrisii (Scudder) ssp.*, Chlosyne hanhami (Fletcher)*, Boloria selene atrocostalis (Huard), Boloria bellona nr. toddi (Holland), Boloria titania grandis (Barnes \& McDunnough), Boloria frigga (Thunberg) ssp.*, Speyeria atlantis atlantis (Edwards), Speyeria atlantis nr. diennisi dos Passos \& Grey, Speyeria cybele cybele (Fabricius), Speyeria aphrodite (Fab. ricius) ssp., Euptoieta claudia claudia (Cramer).

\section{LYCAENIDAE :}

Incisalia augustinus augustinus (Westwood), Incisalia henrici henrici (Grote \& Robinson), Incisalia polios Cook \& Watson, Incisalia eryphon (Boisduval) ssp.*, Incisalia niphon clarki Freeman, Harkenclenus titus titus (Fabricius), Satyrium acadica (Edwards), ssp.*, Satyrium liparops fletcheri (Michener
\& dos Passos, Feniseca tarquinius tarquinius (Fabricius)*, Lycaena thoe Guerin-Meneville*, Lycaena xanthoidies dione Scudder, Lycaena helloides (Boisduval)*, Lycaena dorcas Kirby ssp., Lycaena epixanthe (Boisduval \& LeConte) ssp., Plebejus saepiolus saepiolus (Boisduval), Everes comyntas comyntas (Godart), Everes amyntula albrighti Clench, Glaucopsyche lygdamus couperi Grote, Celastrina argiolus argentata Fletcher.

I am indebted to C. S. Quelch of Transcona, Manitoba, who introduced me to collecting at Sandilands on my first collecting trip to Manitoba in 1966. With Mr. Quelch's guidance I located a rich colony of Oeneis macounii at Sandilands and was so intrigued by their habitat and habits that I launched my studies on the butterflies of Manitoba as well as a series of studies dealing with bionomics of Oeneis.

Good collecting can be found at Sandilands all summer. By the end of May, four species of Incisalia are fairly abundant along with Euchloe ausonides, Erebia discoidalis and Glaucopsyche lygdamus; by mid-June Oeneis macounii, Limenitis arthemis and Papilio glaucus are out in numbers; early July brings out Colias interior, Phyciodes batesii, and the Speyeria species; and August provides the Nymphalis and Polygonia species, Boloria titania, and Satyrium liparops.

\section{LITERATURE CITED}

Masters, J. H., 1972. The butterflies of Manitoba's Provincial Parks II: Grand Beach Provincial Park and Belair Forest Preserve. Blue Jay, $30: 161-166$.

\section{EPIPHYTIC ALGAE ISOLATED FROM MOSS}

\section{by D. R. Cullimore and A. E. McCann, University, Regina}

In the prairie region, mosses are commonly found growing on river and creek banks and also on the open prairie. As a part of the I.B.P. project at Matador, Saskatchewan, attempts were made to evaluate the role of these mosses in the ecological balance of native grassland. Paul, Campbell,
Hedlin and Lees (1972) reported that the leaves of one specific moss, Ceratodon purpureus had a high nitrogen fixing capacity of 0.02 to 1 microgram of nitrogen per hour and that fixation was light and moisture dependent. Samples of moss from Matador and similar samples from Saskatoon pos- 